Удк 343.8

Колб О. Г.,

доктор юридичних наук, професор, професор кафедри кримінального права та процесу Національного університету «Львівська політехніка»

\title{
ПРО ДЕЯКІ ОСОБЛИВОСТІ ЗАСТОСУВАННЯ В УКРАЇНІ ЗАХОДІВ ПРИБОРКАННЯ ДО НЕПОВНОЛІТНІХ, ПОЗБАВЛЕНИХ ВОЛІ
}

У статті здійснено аналіз визначених у законі підстав застосування в Україні до неповнолітніх засуджених, які відбувають покарання у виді позбавлення волі, заходів фізичного впливу, спеціальних засобів та зброї, установлено особливості правозастосовної практики з цих питань, а також розроблені науково обгрунтовані заходи щодо удосконалення зазначеного виду діяльності у сфері виконання покарань.

Ключові слова: особливість, застосування, заходи фізичного впливу, спеціальні засоби, зброя, засуджені, неповнолітні, позбавлені волі, сфера виконання покарань, правові підстави.

В статье осуществлен анализ закрепленных в законе оснований применения в Украине к несовершеннолетним осужденным, отбывающим наказание в виде лишения свободы, средств физического влияния, специальных средств и оружия, установлены особенности правоприменительной практики по этим вопросам, а также разработаны научно обоснованные мероприятия, направленные на усовершенствование данного вида деятельности в сфере исполнения наказаний.

Ключевые слова: особенность, применение, средство физического влияния; специальные средства, оружие, осужденный, несовершеннолетний, лишение свободы, сфера исполнения наказаний, правовые основание.

Постановка проблеми. Вивчення Конституції України засвідчило наявність у її змісті низки норм, які безпосередньо стосуються предмета досліджуваної в цій науковій статті проблематики [1]. Зокрема, у статті 3 Основного закону зазначено, що людина, її життя і здоров'я, честь і гідність, недоторканість і безпека визнаються в Україні найвищою соціальною цінністю. При цьому права і свободи людини визначають зміст і спрямованість діяльності держави, а їх утвердження і забезпечення $є$ головним обов'язком держави.

Більш того, як це витікає із змісту частини другої статті 19 Конституції України, органи державної влади (до яких належать і органи та установи виконання покарань) та їх посадові особи мають діяти лише на підставі, у межах повноважень і в 
спосіб, що передбачені Конституцією та законами України.

У контексті досліджуваної тематики звертають на себе увагу й ті норми Конституції України, що безпосередньо стосуються регулювання суспільних відносин, пов'язаних із застосуванням заходів фізичного впливу, спеціальних засобів і зброї до засуджених, включаючи осіб неповнолітнього віку, про які йдеться в статті 106 Кримінально-виконавчого кодексу (КВК) України [2], а саме:

1) стаття 27 Основного закону, у якій зазначено, що кожна людина має невід'ємне право на життя;

2) стаття 28 - ніхто не може бути підданим катуванню, жорсткому, нелюдському або такому, що принижує його гідність, поводженню чи покаранню;

3) стаття 29 - кожна людина має право на свободу та особисту недоторканість; України.

4) інші норми Конституції

Повною мірою вказані правові положення мають застосовуватися i щодо неповнолітніх, які відбувають покарання у виді позбавлення волі. Як з цього приводу зазначено в статті 52 Конституції України, будь-яке насильство над дитиною переслідується за законом.

Водночас у частині третій статті 106 КВК України вказано, що до неповнолітніх (за міжнародною класифікацією та згідно з Конвенцією про права дитини ці особи мають назву «діти» [3]), які вчиняють груповий або збройний напад чи опір, який загрожує життю і здоров’ю персоналу колонії чи інших осіб, дозволяється застосування заходів фізичного впливу, спеціальних засобів і зброї.
Таким чином, слід визнати, що має місце правова колізія, коли, 3 одного боку (зокрема в статті 52 Конституції України), беззаперечно заборонено застосування насильства до дитини, а, з іншого (частина третя статті 106 КВК), - таке насильство до зазначених осіб визнається правомірним. При цьому, якщо виходити із змісту статті 8 Основного закону, відповідно до якої Конституція України має найвищу юридичну силу, положення частини третьої статті 106 КВК слід визнати таким, що суперечить цьому закону.

Ураховуючи зазначені обставини, без сумніву, досить важливо дати відповідь на дану прикладну проблему і на науковому рівні, що й обумовило вибір цієї статті, iї предмет, мету і головне завдання - розробити науково обгрунтовані пропозиції, спрямовані на вдосконалення правових засад застосування заходів приборкання до неповнолітніх засуджених у місцях позбавлення волі.

Результати вивчення наукової літератури свідчать про те, що досить активно розробленням цієї проблематики займаються науковці, насамперед, так званого адміністративно та кримінально-правового напряму, хоча осторонь цього процесу не залишаються і фахівці кримінально-виконавчого права. До таких, зокрема, можна віднести К. А. Автухова, О. М. Бандурку, В. І. Борисова, $\begin{array}{ll}\text { I. Г. Богатирьова, } & \text { В. В. Василеви- }\end{array}$ ча, В.В.Голіну, Б. М. Головкіна, О. М. Джужу, Т. А. Денисову, С. Ф. Денисова, В. І. Женунтія, В. Я. Конопельского, I. М. Копотуна, М. О. Ліненко, O. М. Литвинова, В. О. Меркулову,
А. В. Саваченка,
А. Х. Степанюка,
В. М. Трубникова,
С. Я. Фаренюка,
I. С. Яковець та ін. 
Поряд із цим досі на доктринальному рівні питання щодо особливостей, $з$ урахуванням конституційних положень, застосування до неповнолітніх у місцях позбавлення волі заходів фізичного впливу, спеціальних засобів і зброї вивчено недостатньо (а це, у свою чергу, впливає на ефективність правозастосовної практики у сфері виконання покарань), що й стало вирішальним при визначенні назви цієї наукової статTi.

Виклад основного матеріалу. Як зазначено в ч. 3, ст. 106 КВК України, забороняється застосовувати заходи фізичного впливу, спеціальні засоби і зброю, поряд з іншими категоріями засуджених, до неповнолітніх, крім випадків учинення ними групового або збройного нападу, які загрожують життю і здоров'ю персоналу колонії чи інших осіб, або збройного опору.

Виходячи 3 цих нормативних положень, можна виокремити такі особливості правозастосовної практики з означених питань:

а) застосування засобів приборкання при груповому нападі неповнолітніх;

б) застосування їх при збройному нападі;

в) застосування зазначених $\mathrm{y}$ законі заходів приборкання при збройному нападі.

У першому випадку відповідь на правомірність та умови на застосування сили до неповнолітніх засуджених можна знайти в роз'ясненнях Пленумів Верховного Суду України, що відображають зміст зазначеної проблематики («Про необхідну оборону» [4], «Про порушення режиму в місцях позбавлення волі» [5]; «Про судовий захист працівників правоо- хоронних органів і суду» [6] та ін.). При цьому основний лейтмотив рішень суду в цьому випадку полягає в тому, що правомірними визнаються дії чи бездіяльність суб'єктів застосування заходів приборкання, якщо іншими засобами чи заходами уникнути цього було неможливо або якщо ці заходи (засоби) не дали очікуваного результату.

Поряд із цим як при уникненні конфлікту, так і при очікуванні настання його результатів суб'єкти правозастосування не мають перевищувати межі необхідної оборони. До таких судова практика відносить:

a) неспіврозмірність засобів нападу та захисту;

б) невідповідність обставин нападу та захисту;

в) неспіврозмірність кількості нападників і кількості осіб, які захищаються;

г) інші ситуації [4].

Ураховуючи зазначене та вимоги ст. 52 Конституції України, слід було б ч. 3 ст. 106 КВК у кінці речення доповнити словосполученням «якщо іншими засобами та заходами насильницькі та інші протиправні дії чи бездіяльність засуджених приборкати не вдалося» та викласти зазначену норму Кодексу в новій редакції.

При цьому під іншими засобами (заходами) приборкання варто розуміти: впливу;

1) вербальні (словесні) методи

2) демонстрацію можливостей спеціальних засобів (зокрема, їх застосування вгору чи в інший бік від засуджених та ін.);

3) звернення до правопорушників найбільш авторитетних у цій ситуації осіб 3 персоналу колонії, 
педагогів чи засуджених, які відбувають покарання;

4) дії психологів та інших подібних фахівців, які мають законний дозвіл проводити лікування громадян (так званих «ворожок», екстрасенсів, душпастирів та ін.).

Щодо другого випадку - застосування до неповнолітніх засуджених у місцях позбавлення волі заходів фізичного впливу, спеціальних засобів і зброї - то у цій ситуації, як свідчить практика, також $є$ свої застереження. Так, у постанові Пленуму Верховного Суду України від 26.04.2002 № 3 «Про судову практику про викрадення та інше незаконне поводження із зброєю, бойовими припасами, вибуховими речовинами, вибуховими пристроями чи радіоактивними матеріалами» зазначено, що у всіх випадках суди зобов'язані встановлювати законність їх застосувань особами, які володіли цими засобами на законних підставах [7]. Якщо зіставити це з проблемами застосування заходів приборкання до неповнолітніх у місцях позбавлення волі, то йдеться про те, що у всіх випадках збройного нападу персонал колоній має усвідомлювати суспільно небезпечні наслідки застосування неповнолітніми засудженими тих чи інших засобів і зброї, та $з$ урахуванням цього протидіяти останнім визначеними у ст. 106 КВК засобами фізичного впливу, спеціальними засобами і зброєю. Так, наявність у неповнолітнього металічної заточки невеликого розміру не може бути підставою для застосування вогнепальної зброї персоналом колонії, якщо при цьому не було небезпечної для зіткнення сторін відстані.

Виходячи з цього, частину третю статті 106 КВК слід було б допов- нити другим реченням такого змісту: «Застосування зазначених засобів i заходів щодо неповнолітнього засудженого дозволяється з урахуванням обставин, що склалися, виду зброї, якою володів правопорушник, а також відстані зіткнення сторін кон $\phi-$ лікту».

Аналогічних умов необхідно дотримуватися також і в третій ситуації, що пов'язана із застосуванням до неповнолітніх засуджених у місцях позбавлення волі зазначених у законі заходів приборкання при збройному опорі.

Про необхідність вирішення цієї проблематики саме з урахуванням зазначеної складової свідчать деякі статистичні дані застосування до засуджених в Україні заходів фізичного впливу, спеціальних засобів і зброї. Зокрема, основною причиною застосування до правопорушників наручників $(62,2 \%$ у структурі застосування всіх заходів приборкання) $\epsilon$ вчинення засудженими фізичного опору (58 \%) та спроби вчинення членоушкодження та самогубства $(23 \%)[8$, c. 22$]$.

Останні також були підставами для застосування до засуджених, позбавлених волі, гумових кийків (99\% у структурі застосування цих спеціальних засобів), фізичної сили (78 \%), спеціальних засобів дратівної дії (92\%) та гамівної сорочки (100 \%) [8, c. 23].

Загалом же аналіз випадків застосування заходів приборкання до засуджених у місцях позбавлення волі засвідчив, що основною причиною їх застосування стало учинення останніми фізичного опору або проявів буйства (67 \% від загальної кількості) [8, с. 23], які, у свою чергу, є невід'ємними складовими елемента- 
ми групового або збройного нападу та збройного опору правопорушників у колоніях, що тільки підтверджує актуальність досліджуваної в цій науковій публікації проблематики та акцентує увагу учених і практиків на необхідності її вирішення на доктринальному, практичному (правозастосовному) та нормативноправовому рівнях [9].

Звичайно, що методологічним підгрунтям для вдосконалення правового механізму з означених питань могло би стати рішення Конституційного Суду України щодо відповідності ч. 3 ст. 106 КВК України ст. 52 Конституції України. Проте очевидним $є$ й інший факт: без кількісних напрацювань у науці і теоретикам, i практикам, і суддям приймати виважені, обгрунтовані та законні рішення по суті буде й надалі вкрай важко.

Тим більше, що й інші положення ст. 106 КВК України, які стосуються застосування заходів приборкання до неповнолітніх засуджених у місцях позбавлення волі, крім частин 5 та 6 цієї статті Кодексу, не видозмінювалися 3 часу його прийняття (11 липня 2003 р.) [2], при тому, що за цей час вийшов новий Кримінальний процесуальний кодекс України [10], Закон України «Про Національну поліцію» [11], «Про прокуратуру» [12] та інші нормативно-правові акти, які різною мірою стосуються питань застосування заходів фізичного впливу, спеціальних засобів і зброї до засуджених, позбавлених волі.

Висновки. Отже, урахування особливостей застосування заходів приборкання до неповнолітніх засуджених у місцях позбавлення волі має не тільки і не стільки пізнавальне (теоретично-доктринальне), як прикладне значення, позаяк це питання тісно пов'язане з конституційними положеннями та міжнародноправовими вимогами, що визначають правовий статус цих осіб.

\section{Список використаних джерел}

1. Конституція України : прийнята 28 червня 1996 року. Відомості Верховної Ради України. 1996. № 30. Ст. 141.

2. Кримінально-виконавчий кодекс України : прийнятий 11 липня 2003 року. Відомості Верховної Ради України. 2004. № 3-4. С. 21.

3. Конвенція ООН про права дитини. Законодавство України. URL: http://zakon.rada.gov.ua/laws/show/995_021 (дата звернення: 17.08.2018).

4. Про судову практику в справах про необхідну оборону Постанова Пленуму Верховного Суду України від 26.04.2002 №1. Постанови Пленуму Верховного Суду України в кримінальних справах / упоряд.: В. В. Рожнова, А. С. Сизоненко, Л. Д. Удалова. Київ, 2011. С. 169-171.

5. Про судову практику в справах про злочини, пов'язані з порушеннями режиму відбування покарання в місцях позбавлення волі : Постанова Пленуму Верховного Суду України від 26 берез. 1993 р. № 2. Постанови Пленуму Верховного Суду України в кримінальних справах / упоряд.: В. В. Рожнова, А. С. Сизоненко, Л. Д. Удалова. Київ, 2011. С. 109-116.

6. Про застосування судами законодавства, що передбачає відповідальність за посягання на життя, здоров'я, гідність та власність судів і працівників правоохоронних органів : Постанова Пленуму Верховного Суду України від 26 червня 1992 р. 
№ 8. Постанови Пленуму Верховного Суду України у кримінальних справах / упоряд.: В.В. Рожнова, А.С. Сизоненко, Л. Д. Удалова. Київ, 2011. С. 100-108.

7. Про судову практику про викрадення та інше незаконне поводження із зброєю, бойовими припасами, вибуховими речовинами, вибуховими пристроями чи радіоактивними матеріалами: Постанова Пленуму Верховного Суду України від 26.04.2002 № 3. Постанови Пленуму Верховного Суду України у кримінальних справах / упоряд.: В. В. Рожнова, А. С. Сизоненко, Л. Д. Удалова. Київ, 2011. С. 176-182.

8. Про діяльність підрозділів охорони, нагляду та пожежної безпеки установ виконання покарань у 2016 році : інформ. бюл. Київ : Міністерство юстиції України, 2017. 43 c.

9. Попов Г. В Захист прокуратури прав і свобод дітей: монографія. Київ: Видавничий дім «Арт Ек», 2016. 384 с.

10. Кримінальний процесуальний кодекс України: прийнятий 13 квітня 2012 року. Відомості Верховної Ради України. 2013. № 9-10, № 11-12, № 13. Ст. 88.

11. Про Національну поліцію : Закон України від 2 липня 2015 року № 580-VIII. Відомості Верховної Ради України. 2015. № 40/41. Ст. 379.

12. Про прокуратуру : Закон України від 14 жовтня 2014 р. № 1697-VII // Відомості Верховної Ради України. 2015. № 2/3. Ст. 12.

\section{O. Kolb,}

Doctor of Law, Professor,

Professor of the Department of Criminal Law

and Process of the Lviv Polytechnic

National University

\section{PECULIARITIES OF THE APPLICATION TO THE JUVENILE PRISONERS OF INFLUENCE MEASURES IN UKRAINE}

The article analyzes the grounds for the use in Ukraine of juvenile convicts serving sentences in the form of deprivation of liberty, measures of physical impact of special weapons, as well as the peculiarities of law enforcement practice on these issues, as well as scientifically substantiated measures aimed at improving this type of activity in the field of execution of punishment.

Taking into consideration the specific coercion measures to the juvenile convicts at the places of deprivation of liberty has not only the cognitive (theoretical and doctrinal) significance, but also the practical one, because that issue is closely related to the constitutional provisions, which determine the legal status of such persons, as well as to the international legal requirements, which determine the legal status of such persons.

Key words: feature, application, measures of physical influence, special means, weapon, condemned minors, deprived of liberty, scope of punishment, legal grounds.

Надійшла до редакції 18.10.2018 